\title{
26. 眼振の変動と前庭外要因
}

○江上徹也 - 沢田正道 - (長崎大) 渡辺 勈（東医菌大）

眼振は種々の前庭外要因により変動するが日常の平衡 機能険查に際しても前庭外要因の配慮により異常検出率 の増大や疾患の背景を探るらえで有用な場合がある，眼 振を促進する要因として暗算負荷の他に, 閐眼時眼瞼が 不随意的に活動して眼振が記録しにくい例で法両眼瞼を 軽く指頭で圧迫すると規則的な眼振が記録される。内耳 瞵接の器官や神経が内耳に影響を与える例として(1)咬合 運動で眼振が誘発される頽関節症候を伴なつたメニエー ル病。(2)健側の三叉神経領域を痛覚刺激すると同側向き 眼振が誘発されるが，麻㾇側刺激では変化しない末梢性 三叉神経麻㾝症例．を例示した．息こらえ，バルサルバ や，“開眼:は末梢性自発眼振や温度性眼振を抑制する 要因であるが，頭蓋内病変のある例ではこれらの因子が 抑制的な作用を示すことが少なく逆に促進的に作用する ことが少なくないので，中枢，末梢障害の鑑別の資料と して利用できることがある．眼振とは異なるが，振子様 の律動的眼球変動が長時間息こらえをしたあと出現する 現象を認めたので，重心動摇，呼吸眼運動を同時記録し て自己相関，周波数分析を行なった。眼運動は呼吸と経 過，周波数とも関連が深く，自然に呼吸をしている時は
呼吸との相関は認められないので，息こらえによる呼吸 中枢の興窨が，眼運動系に影響を与えて呼吸性眼球変動 を生じたと推定した，Alartness 低下時の振子様眼運動 は呼吸との関係は密接なものはみられなかつた。

前庭外要因一の配慮は(1)眼振の誘発や規則的な記録, (2)めまい，眼振の背景の推定，(3)中枢，末梢鑑別の資料 (4)前庭系, 眼運動系の関連についての解䣋, などの点で 臨床的意義が認められる。

質問 竹森節子 (帝京大). 実駼性眼振の種類による 開発の差異はなかつたか. 応答 江上徹也（長大）. 実験性眼振はすべて温度刺激によつた。質問 調重 炤（福岡大）．呼吸中枢與鹤剂テラプチックの息こらえ 眼球運動などへの影響を検討したか。応答 江上徹 也（長大)．テラプチックの影響は今回は検討していな いが，呼吸中枢の興偣が眼運動に影響を与えた現象と推 定している. 質問 鈴木淳一（帝京大）. slow undulation は，確実に眼球運動とみてよいか 応答 江上徹也 (長大). 息こら光後の振子様運動は, フレン ツェル眼鏡下や，関眼で接触しても認められるので，眼 球運動そのものと考える.

\section{7. めまいに対する自律神経中枢の役割りについての基礎的考察}

○松永 亭. 久保武・榣留欣一・佐野光仁 (関西労织)

最近増加しつつあるめまいの原因または成因として， 自律神経系, 内分泌系の異常, 精神的ストレスなどのよ り機能的な障害を考える必要がある。自律神経系のう ち，めまいに対し末梢のそれの関与の仕方は前庭性自律 神経反射としてよく知られている。しかし中枢自律神経 系がめまいにどのように関係するかは充分知られていな い内分泌系に関しては視床下部での Releasing Factor の存在が認められるよらになり，視床下部・下垂体系の 仕組みが判明してきた。ささらに精神的ストレスにおいて 大胀辺縁系, 視床下部の関連が認められている．以上の 観点は自律神経中枢としての視床下部がめまいの発現に ある役割を有することを推測させるので，今回この役割
の存在を基礎的に究明しようとした。

実験はすべて純系雄性白色ラットで行なつた。エーテ 儿麻酥下気管切開, 人工呼吸, ガラミン不動化のもと, 定位的に前庭神経核に微小硝子電極を刺入し, 単一二ニ 一ロンの放電を記録，振子様回転刺激への反応態度から 前庭神経核ニューロンの導定を行なつた。視床下部には 4 本のステンレス刺激電極を插入した。視床下部内側野 で腹内側核のレベルでの中部視床下部の刺激ではすべて 前庭神経核に陰性波を示す加算誘発電位を認め, また自 発放電は抑制されるものが多かつた．視床下部外側野で 前部視床下部の刺激では時に前庭神経核に陽性波を示す 加算誘発電位を認め, また，自発放電は促進されるもの 
が多かつた．回転に対し Type I で反応するニューロン はType II ニューロンょりむ視床下部の通電刺激に反応 する嚬度が高かかつた。ささらにアドレナリンの静注は自 発放電の抑制を，一方ノルアドレナリンの静注注促進を もたらすことを認めた，視床下部の通電刺激恃その刺激 部位により，アドレナリンノルアドレナリンの量的構成 の差をもつた分泌上昇を惹起することが知られている。

したがつて視床下部の省は neural 又は humoral の経 路を介し前庭系の雀に影響をあたえ, めまい発生の要 因となり得ると考えた。

質問 洔田 夸(岐大). 自律神経系が迷路性めまい に関与すると思らが, この場合, 臨床的には前庭系に異 常を認めない例が多い，この点をどう考えるか。応 答 松永 亨 (関西労绝)。1）視床下部がめまいに関
係寸ると考えたのは，めまい患者に起立性失調症，ある 、はホルモン療法に奏効するものがあるからである、、 ずれにしてを，自律神経系の血流への影響以外，体性神 経系への影響が問題になることを提起した。

質問 檜 学 (徳大). 海馬の反䨱電気刺激で，特発性眼振の 出現, 脳波の覚醒度の高揚, またある種の動物では左右 差ある瞳孔散大を経験しているが，演者の実験でこのよ らな現象はみられなかつたか。応答 松永 亨(関 西労多) 中部視床下部刺激では（6交感帯に相当）䁪孔 散大を引き起す，前部視床下部刺激では睡孔所見に関し て一定しない以上はガラミンの効果が消失してきたと きの所見である、なお前部視床下部刺激ではラットの尾 で測定した血圧壮低下する。

\title{
28. 海馬反覆電気刺激で誘発される眼振, 眼球運動;
}

ヒトの心因性めまい解明の神経耳科学的アプローチ

\author{
O中西和 仁・檜学 (徳大)
}

海馬に電極を挿入し，一定量( $1 \mathrm{msec}, 200 \mathrm{~Hz}$ ，パルス. $3 \mathrm{~V} ， 30$ 秒) の電気刺激を反徱加え，この操作で起る ENG, EEG (海馬, 中脳網様体，大脑皮質）の变化を 同時記録した，成績は次のように要約される．（价正常ウ サギでも海馬に電気刺激を反覆加えると眼振をみるょう になる。 (口片側腰部脊柱起立笳樑部受容器や片側末梢迷 路に機能障害が与えられ，二次的に潜在性脳幹機能異常 が設定されているウサギでは，海馬電気刺激でより容易 比且つ明䀢に眼振が誘発される。この際出現する眼振 は，そ礼らの動物がかつて示した特発眼振に相似する。 小海馬電気刺激で誘発される眼振は，何れの場合も刺激 中止後一定時間をへて出現し始めること多く、眼振出現 に際して脳波江覚醒の度を高める。

上述の眼振発現機序はなお不明の点が多いが，海馬上 脳幹, 特に中脳外側部腹側被蓋野が脳弓，視床下部又は 視床旁下部を介して密接に線維連絡する事実より推測す ると，その機序の一つを，海馬上りの下行性インバルス の中脳外側部腹側被蓋野への影響に求めて上いと考え る.この考え注，腰部脊柱起立笳への反覆電気刺激や片 側末梢迷路損傷で上述の脳分野に潜在性機能異常が予め 設定されている場合には，より容易に，且つそれぞれに
特徵的な眼振が誘発される事実より支持される。また， 眼振, 特にその速期解発に大略一致して脑波が覚醒の度 を高める事実よりも支持をうける。なお，海馬が情動 の発動, 記憶, 条件反射形成に重要な役割を果すこと, 並びに頭頚部外傷例などで心因性めまいと診断されたも のでは記憶に基づく情動発動と関連してめまい，平衡失 調が誘発，增強されることが少くないこれらの事実を 併せ考えると，上述のウサギの成續はヒトの心因性めま い発現機序解明に貴重な資料となる。

質問 江上徽也（長大）．末梢迷路破壊による旧在の 眼振が海馬刺激で再現される現象の機序をどのよ5に考 えるか. 応答 中西和仁 (徳大). その発生機序に ついては，Nauta らの解剖学的事実やわれわれの実験結 果加方, 脳弓, 視床下部, 中媨被蓋野の経路を介して, 中脳網様体のレベルで，海馬上層の遠心性インパルスの 影響で眼振が誘発されると考えている，なお，海馬より 視床下部を介して前庭神程核への直接的影響も否定でき ない追加・㐫答 檜 学 (德大). 大脑辺縁系, とくに海馬は記憶, 情動に関連する脳であり，これと中 脳辺縁系とくに中这外側腹側部は密接に線維連絡し，加 つ後者は上行性䟼活系の部位にあたる。従つて，情動の 